\title{
Evidence That Calcitonin Stimulates 1,25-Dihydroxyvitamin D Production and Intestinal Absorption of Calcium In Vivo
}

\author{
Philippe Jaeger, William Jones, Thomas L. Clemens, “ and John P. Hayslett \\ Department of Medicine, Yale University School of Medicine, New Haven, Connecticut; Helen Hayes Hospital,* West Haverstraw, \\ New York; and Department of Clinical Pathology,* Columbia University, New York, 10032
}

\begin{abstract}
Although it is well established that parathyroid hormone and phosphate are important regulators of 1,25-dihydroxyvitamin D $\left[1,25(\mathrm{OH})_{2} \mathrm{D}\right]$ production, it remains unclear whether calcitonin affects vitamin D metabolism in vivo. Experiments were performed in the rat to determine the effect of chronic calcitonin infusion $\left(0.2 \mathrm{U} \cdot \mathbf{h}^{-1}\right)$ on plasma levels of vitamin $D$ metabolites and on calcium metabolism. Thyroparathyroidectomized animals fed a calcium-replete or calcium-free diet were studied for as long as 2 wk before they were killed. In control rats, a calciumfree diet alone for $12 \mathrm{~d}$ resulted in an increase in $1,25(\mathrm{OH})_{2} \mathrm{D}$ levels from $24 \pm 5$ to $139 \pm 37 \mathrm{pg} \cdot \mathrm{ml}^{-1}, P=0.025$. The infusion of calcitonin also stimulated $1,25(\mathrm{OH})_{2} \mathrm{D}$ levels compared with controls on a regular diet $\left(80 \pm 17\right.$ vs. $\left.38 \pm 6 \mathrm{pg} \cdot \mathrm{ml}^{-1}, P<0.05\right)$ and on a calcium-free diet $\left(460 \pm 50\right.$ vs. $139 \pm 37 \mathrm{pg} \cdot \mathrm{ml}^{-1}, P$ $<0.001)$. In addition, calcitonin increased plasma calcium levels in animals on a regular diet by $\mathbf{5 0 \%}$; this effect was most likely due to increased intestinal absorption of calcium, because removal of calcium from the diet markedly blunted this effect. In contrast, calcitonin administration did not significantly affect $25(\mathrm{OH}) \mathrm{D}$ plasma levels. Collectively, these data suggest that calcitonin and calcium are independent regulators of $1,25(\mathrm{OH})_{2} \mathrm{D}$ production and that calcitonin stimulates intestinal absorption of calcium, by increasing circulating levels of $1,25(\mathrm{OH})_{2} \mathrm{D}$.
\end{abstract}

\section{Introduction}

Although it is well known that acute administration of calcitonin causes hypocalcemia and hypophosphatemia, the effect of calcitonin on vitamin D metabolism is unclear. Galante and associates (1) reported that infusion of calcitonin increased the production of 1,25-dihydroxyvitamin $\mathrm{D}\left[1,25(\mathrm{OH})_{2} \mathrm{D}\right]^{1}$ in the vitamin D-deficient rat. This finding, however, was not confirmed by other workers in the vitamin D-deficient chick (2) or in the thyroparathyrodectomized (TPTX) rat (3). Recent studies by Horiuchi and associates (4) have reported that calcitonin administration was associated with increased conversion of $\left[{ }^{3} \mathrm{H}\right] 25$ hydroxyvitamin $\mathrm{D}$ into $\left[{ }^{3} \mathrm{H}\right] 1,25$ dihydroxyvitamin $\mathrm{D}$ in vitamin

Address reprint requests to Dr. Jaeger, Department of Internal Medicine, University Hospital (CHUV), 1011 Lausanne, Switzerland.

Received for publication 11 September 1985 and in revised form 15 April 1986.

1. Abbreviations used in this paper: HPLC, high pressure liquid chromatography; $1,25(\mathrm{OH})_{2} \mathrm{D}, 1,25$-dihydroxyvitamin $\mathrm{D} ; \mathrm{TPTX}$, thyroparathyroidectomy.

J. Clin. Invest.

(C) The American Society for Clinical Investigation, Inc.

$0021-9738 / 86 / 08 / 456 / 06 \quad \$ 1.00$

Volume 78, August 1986, 456-461
D-deficient TPTX rats, and Kawashima and associates (5) have demonstrated that calcitonin stimulates $25(\mathrm{OH}) \mathrm{D}-1 \alpha$-hydroxylase, in vitro, in the proximal straight tubule of rat kidney. However, the interpretation of these studies is confounded by the use of vitamin D-deficient animals, because vitamin $\mathrm{D}$ deficiency generated prior to TPTX alters $1 \alpha$-hydroxylase activity, and by experimental conditions in which changes in plasma levels of calcium, phosphate, or parathyroid hormone, three independent modulators of $1,25(\mathrm{OH})_{2} \mathrm{D}$ formation, are present.

The present studies were therefore performed to determine whether chronic infusion of calcitonin directly stimulates $1,25(\mathrm{OH})_{2} \mathrm{D}$ generation in vivo, independently of parathyroid hormone, vitamin $\mathrm{D}$ deficiency, or changes in plasma levels of calcium or phosphorus. The results show that calcitonin directly stimulates $1,25(\mathrm{OH})_{2} \mathrm{D}$ production which, in turn, increases intestinal absorption of calcium.

\section{Methods}

Male Sprague-Dawley rats from Camm Research Laboratories (Wayne, $\mathrm{NJ}$ ) were used in all experiments, and weighed 220-290 g. Thyroparathyroidectomy (TPTX) was performed under microscopic vision and ether anesthesia, and the glandular tissue was removed by blunt dissection. Adequacy of the procedure was assessed by the level of serum calcium after a 16-h fast on the second day after surgery. Animals were selected for further study only if serum calcium was below. $1.75 \mathrm{mmol} \cdot$ liter $^{-1}$. Normal serum calcium was $2.48 \pm 0.04($ mean \pm SEM, $n=30$ ) $\mathrm{mmol} \cdot \operatorname{liter}^{-1}$. All TPTX animals were administered $4 \mu \mathrm{g}$ of L-thyroxin (Levotyroid, Armour Pharmaceutical Co., Kankakee, IL) three times weekly, as previously described (6). Four groups of animals were studied:

Group $A$. This group was fed a regular diet and received no infusion.

Group $B$. This group was also fed a regular diet and was infused with salmon calcitonin (Calcimar, Armour Pharmaceutical Co.) at a constant rate of $0.2 \mathrm{U} \cdot \mathrm{h}^{-1}$ (MRC international units).

Group $C$. These animals were fed a calcium-free diet and received no infusion.

Group D. These animals were also fed a calcium-free diet and were infused with salmon calcitonin at a constant rate of $0.2 \mathrm{U} \cdot \mathrm{h}^{-1}$.

Calcitonin was administered by osmotic minipumps (model 2002, Alzet, Palo Alto, CA). The pumps were implanted subcutaneously in the interscapular space under pentobarbital anesthesia $(5 \mathrm{mg} \cdot 100 \mathrm{~g}$ body $\left.\mathrm{wt}^{-1}\right)$. A sham implantation was performed under similar conditions in animals that did not receive the hormone infusion.

The experimental diets were begun at the time of implantation. The regular diet was autoclavable rodent laboratory chow No. 5010 (Ralston Purina Co., St. Louis, MO), and contained $1.2 \% \mathrm{Ca}, 0.8 \% \mathrm{P}$, and $8.8 \mathrm{IU}$ vitamin $\mathrm{D}$ per $\mathrm{g}$ of food. The calcium-free food was prepared in our laboratory, as previously described (7), and contained $0.001 \% \mathrm{Ca}, 0.8 \%$ $\mathrm{P}$, and 2.13 IU vitamin D per $\mathrm{g}$ of food. Access to food was restricted to the period from 1800 hours to 0800 hours. Animals on the regular diet had free access to tap water, whereas those on the calcium-free diet had free access to distilled water.

After surgery animals were observed for 6 or $13 \mathrm{~d}$. Samples of blood were obtained from the tail on days $3,5,7,10$, and 12 for the determination of hematocrit, total calcium, and inorganic phosphorus. On 
the morning of the 6th or 13th day, after a 24-hr fast, animals were anesthetized with pentobarbital and exsanguinated via a polyethylene catheter tied into the right carotid artery. This blood was used for the determination of plasma $25(\mathrm{OH}) \mathrm{D}$ and $1,25(\mathrm{OH})_{2} \mathrm{D}$ as previously described (8). Briefly, 1-2 ml of plasma were extracted with acetonitrile and then chromatographed on C-18 Sep-Pak cartridges (Waters Associates, Division of Millipore Corp., Milford, MA) followed by high pressure liquid chromatography (HPLC). The $25(\mathrm{OH}) \mathrm{D}$ region eluting from HPLC was collected and quantitated by competitive protein binding assay. The $1,25(\mathrm{OH})_{2} \mathrm{D}$ collected from HPLC was assayed in a specific radioimmunoassay. The intra- and interassay coefficients of variation for this method are $7 \%$ and 10\%, respectively. Intact rats (220-290 g) on a calcium and phosphorus-sufficient diet had an average plasma $1,25(\mathrm{OH})_{2} \mathrm{D}$ concentration of $79 \pm 23 \mathrm{pg} \cdot \mathrm{ml}^{-1}($ mean $\pm \mathrm{SD}, n=7)$.

Calcium and inorganic phosphorus were measured by spectrophotometry, the former using cresolphtalein complexone (9) and the latter by a modification of the technique by Daly and Ertingshausen (10) using ammonium molybdate.

Results are presented both as individual data and as mean \pm SEM. Statistical comparisons were performed by the paired and unpaired Student's $T$ tests; a $P<0.05$ was considered to be significant.

\section{Results}

The plasma calcium levels of individual animals followed for 6 or $12 \mathrm{~d}$ are shown in Fig. 1. On the regular diet, control animals remained persistently hypocalcemic throughout the period of observation, as expected (Fig. $1 A$ ). Infusion of calcitonin at the rate of $0.2 \mathrm{U} \cdot \mathrm{h}^{-1}$ (Fig. $1 \mathrm{~B}$ ) increased plasma calcium to the low normal range by day 5 , and plasma calcium remained in the normal range through day 12. Compared with calcium levels at day 0 , calcium level increased by $50 \%(P<0.001)$ by day 9 . On the calcium-free diet plasma calcium levels remained low, and gradually fell during the course of the study in the shamimplanted animals (Fig. $1 C$ ). In contrast to the calcitonin-treated group on a regular diet, the calcitonin-treated group on the calcium-free diet was characterized by persistent hypocalcemia through day 12 (Fig. $1 \mathrm{D}$ ), although calcium levels increased by $15 \%$ by day $12(P<0.02)$ compared with day 0 .

Plasma phosphate levels of individual animals are depicted in Fig. 2. It is apparent that the procedure of TPTX resulted in hyperphosphatemia in all animals and that plasma phosphate levels were not significantly altered during the period of observation in any of the groups. Rats in group B, however, were found to have slightly lower plasma phosphate levels than rats in the other groups by the end of the follow-up period, probably owing to the higher plasma calcium levels recorded in these animals. It should be noted, however, that the plasma phosphate levels in the two groups fed a regular diet were not significantly different on day 6 , in the absence $(4.26 \pm 0.18 \mathrm{mmol} / \mathrm{liter}, n=11$,

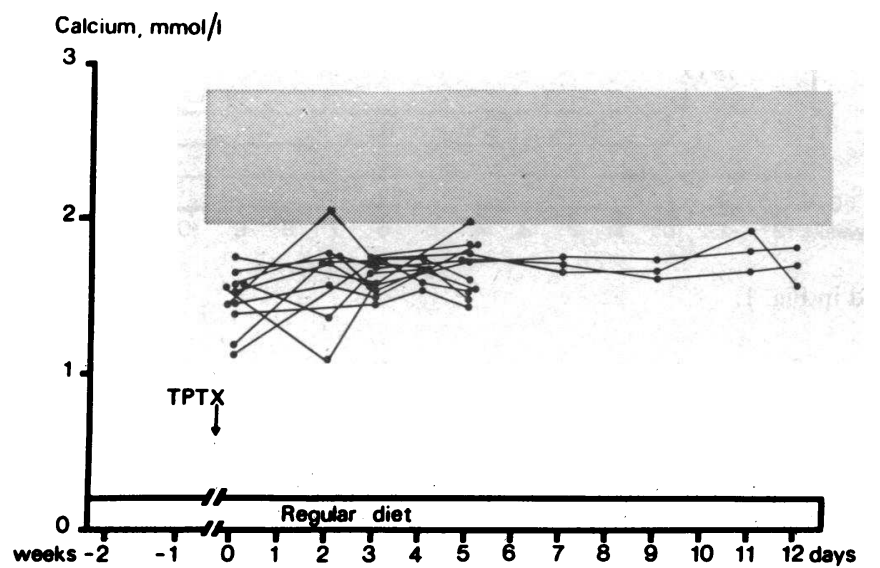

C

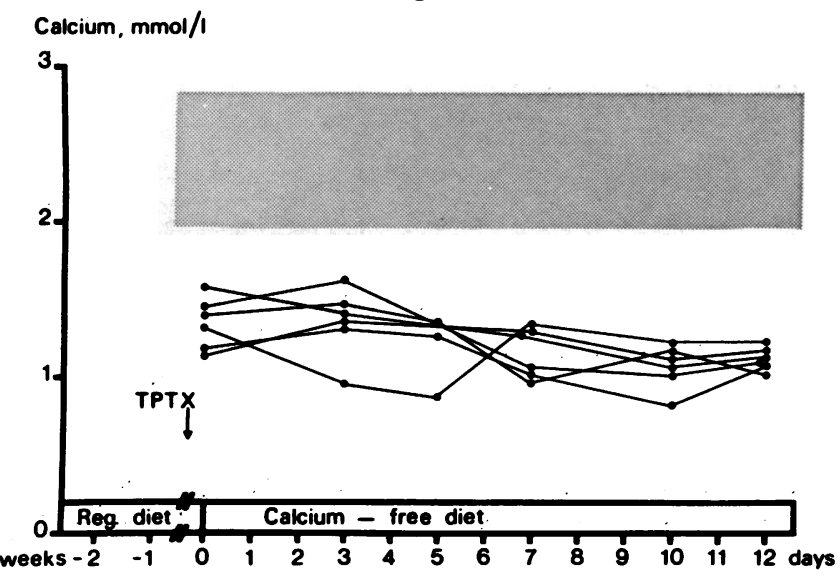

B

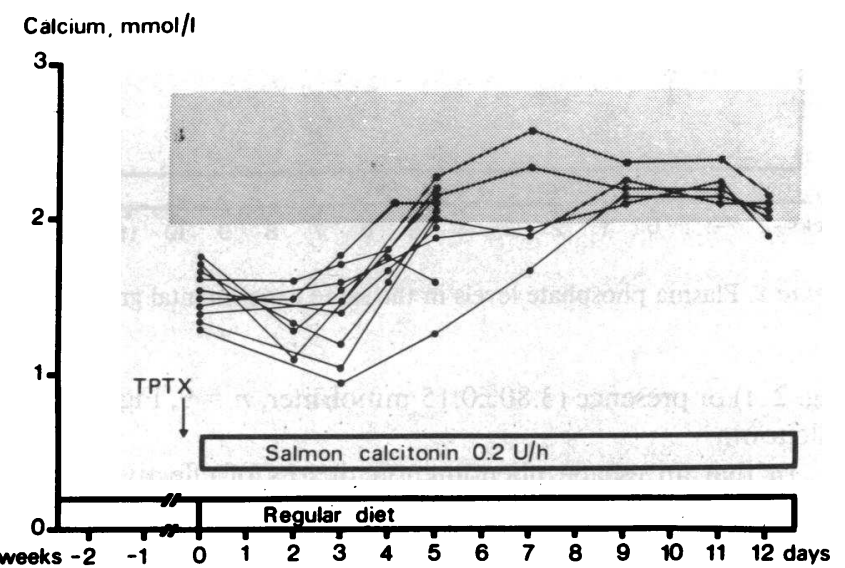

D

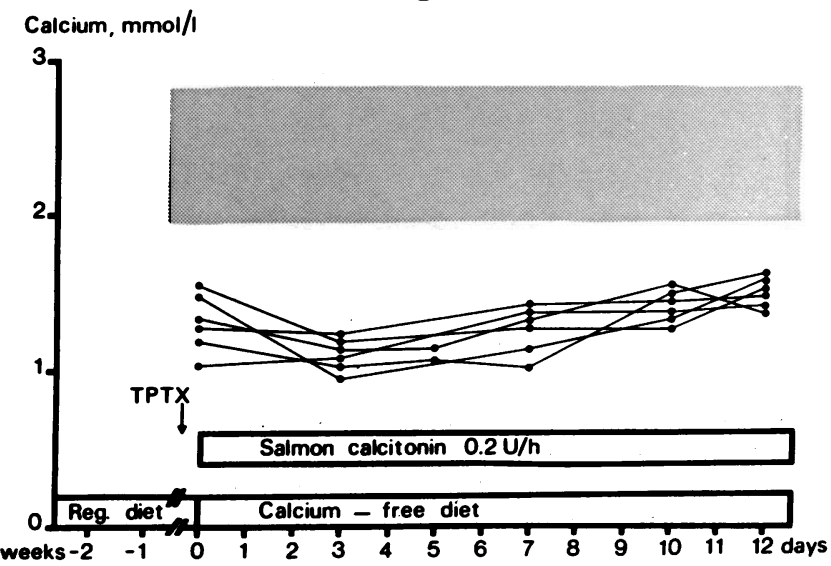

Figure 1. Plasma calcium levels in the four experimental groups: group A, regular diet and no infusion of calcitonin; group B, regular diet with calcitonin infusion; group C, calcium-free diet and no infusion of calcitonin; group D, calcium-free diet with calcitonin infusion. Abbreviation: 1, liter. The shaded areas represent the normal range of plasma levels in thyro-parathyroid intact animals. 
A
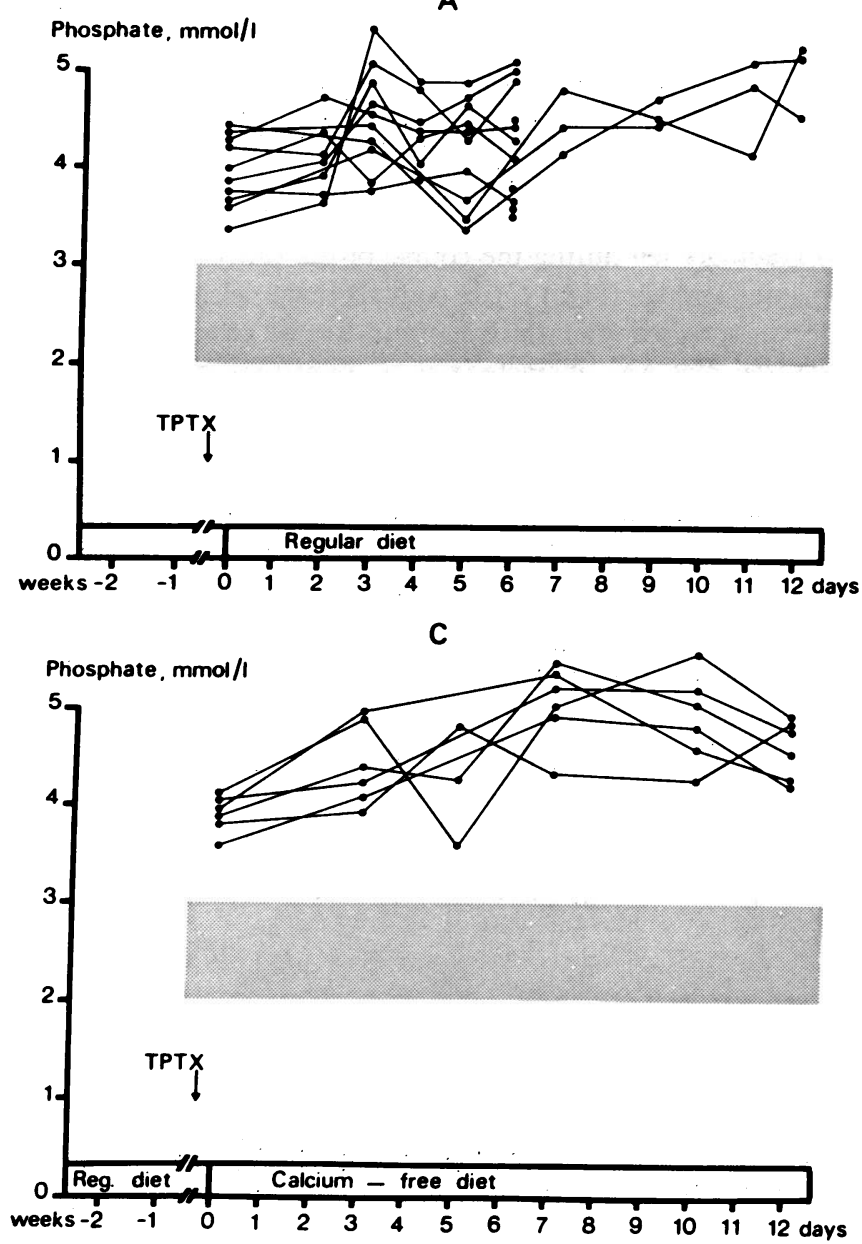

B
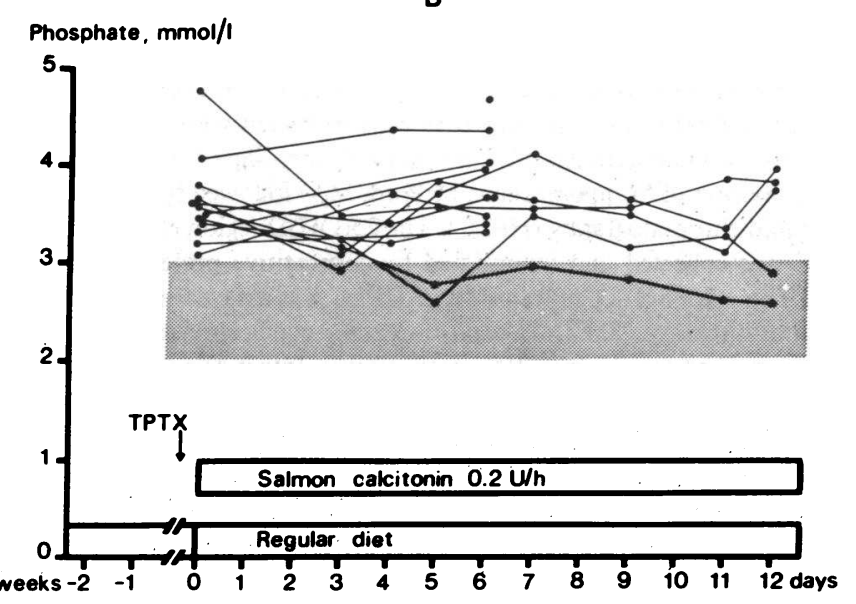

D

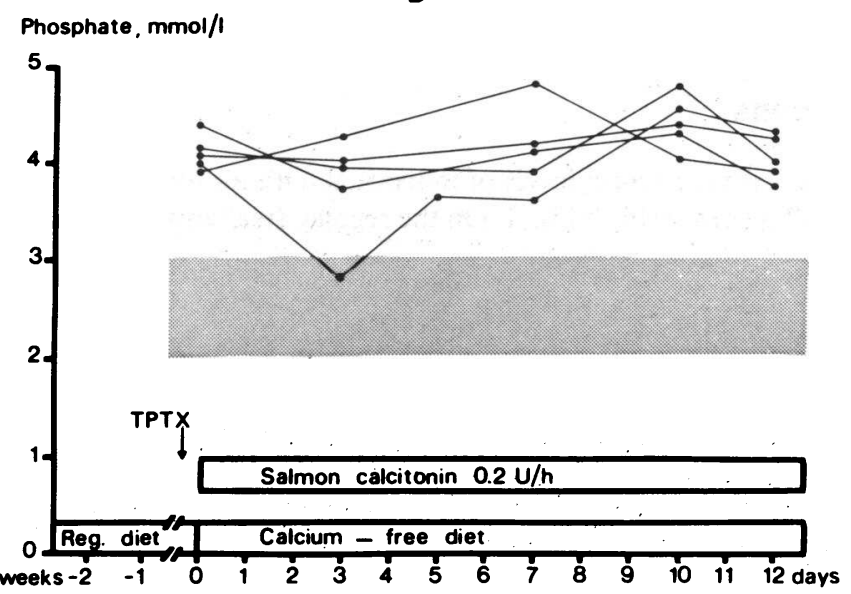

Figure 2. Plasma phosphate levels in the same experimental groups described in Fig. 1.

Fig. $2 A)$ or presence $(3.80 \pm 0.15 \mathrm{mmol} / \mathrm{liter}, n=9$, Fig. $2 B)$ of calcitonin.

In that an escape phenomenon or loss of effectiveness of calcitonin on bone metabolism has been reported during chronic administration (11), studies were performed to determine whether tolerance to the action of calcitonin had occurred after 6 or more days of treatment. As shown in Fig. 3, the administration of a bolus of 1 or $10 \mathrm{U}$ of calcitonin on days 6,10 , and 11 induced the expected depression of plasma levels of calcium and phosphate in animals on chronic calcitonin infusion. He-
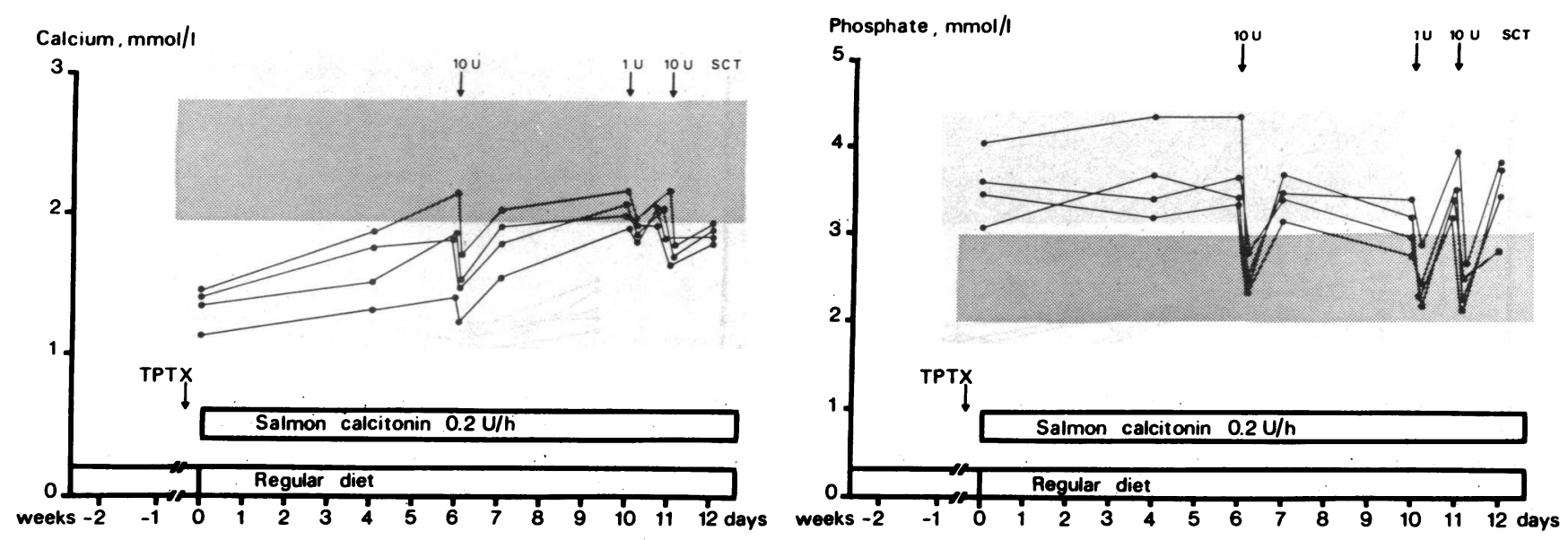

Figure 3. Effect of acute bolus injections of calcitonin in doses of 1 and $10 \mathrm{U}$ on plasma calcium and phosphate levels during chronic infusion of calcitonin. 
matocrit was also measured to determine whether chronic calcitonin administration had induced volume contraction, due to its natriuretic properties $(12,13)$. Calcitonin caused a modest increase in hematocrit of $14 \%$ on day $4(P<0.02)$. This change was not persistent, however, and the hematocrit values of $47.4 \pm 0.9 \%$ (calcitonin) and $49.1 \pm 0.7 \%$ (sham) on day 12 were not statistically different.

To determine whether calcitonin stimulated vitamin $\mathrm{D}$ production, plasma levels of $25(\mathrm{OH}) \mathrm{D}$ and $1,25(\mathrm{OH})_{2} \mathrm{D}$ were measured on days 6 and 13. There were no significant changes in 25(OH)D levels during calcitonin infusion on either diet. On day 12 the $25(\mathrm{OH}) \mathrm{D}$ levels in animals on a regular diet were $8.0 \pm 1.8 \mathrm{ng} \cdot \mathrm{ml}^{-1}$ (control) and 5.6 \pm 1.1 (calcitonin), $P=\mathrm{NS}$, whereas on a calcium-free diet the levels were $5.3 \pm 0.3 \mathrm{ng} \cdot \mathrm{ml}^{-1}$ (control) and 9.2 \pm 1.9 (calcitonin), $P=$ NS. Inspection of Fig. 4 , shows that $1,25(\mathrm{OH})_{2} \mathrm{D}$ levels were influenced by both the dietary regimens and calcitonin. In control animals plasma $1,25(\mathrm{OH})_{2} \mathrm{D}$ levels increased by day 12 from $24 \pm 5$ on regular diet to $139 \pm 37 \mathrm{pg} \cdot \mathrm{ml}^{-1}(P=0.025)$ on calcium-free diet, indicating a direct stimulatory effect of calcium depletion on production of this hormone. A stimulatory effect of calcitonin on $1,25(\mathrm{OH})_{2} \mathrm{D}$ production was demonstrated on both dietary regimens. At day 6 on the regular diet plasma levels of $1,25(\mathrm{OH})_{2} \mathrm{D}$ were higher in the calcitonin-infused animals, than in untreated counterparts $\left(80 \pm 17\right.$ vs. $\left.38 \pm 6 \mathrm{pg} \cdot \mathrm{ml}^{-1}, P<0.05\right)$; at day 12 on this diet, however, the levels of $24 \pm 5$ and $28 \pm 1 \mathrm{pg} \cdot \mathrm{ml}^{-1}$ in the same groups, respectively, were not statistically different. At day 12 on the calcium-free diet plasma levels of $1,25(\mathrm{OH})_{2} \mathrm{D}$ were higher in the calcitonin-infused than in the untreated rats $\left(460 \pm 50 \mathrm{pg} \cdot \mathrm{ml}^{-1}\right.$ vs. $\left.139 \pm 37, P<0.001\right)$. Inasmuch as the group treated with calcitonin on the regular diet was relatively hypercalcemic on day 12 , it seems likely that $1,25(\mathrm{OH})_{2} \mathrm{D}$ production was suppressed by the increased plasma calcium levels. In contrast, in the group on the calcium-free diet the stimulatory action of calcitonin was unimpeded because calcium levels persisted in a hypocalcemic range.

\section{Discussion}

Previous studies in animals and humans have demonstrated that conversion of $25(\mathrm{OH}) \mathrm{D}$ to $1,25(\mathrm{OH})_{2} \mathrm{D}$ is stimulated by para-

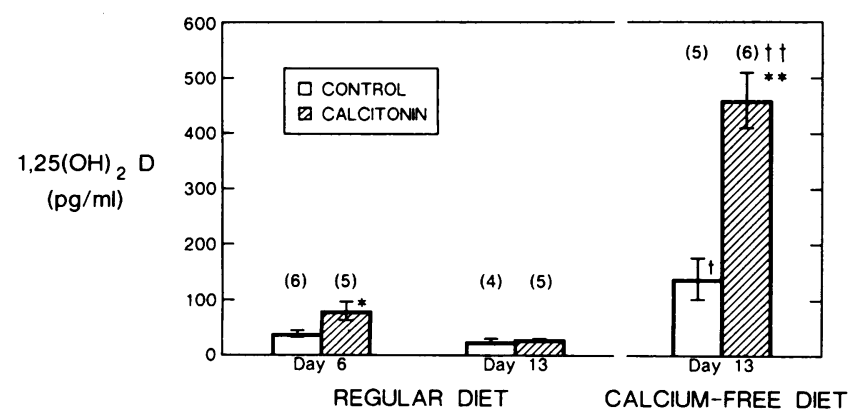

Figure 4. Plasma levels $( \pm \mathrm{SEM})$ of $1,25(\mathrm{OH})_{2} \mathrm{D}$ in control and calcitonin-infused animals on a regular and calcium-free diet. The numbers in parentheses indicate the number of animals per treatment group. ${ }^{*} P<0.05$ and ${ }^{* *} P<0.001$ compared with controls of the same day on the same diet. $\dagger P=0.025$ and $\dagger \dagger P<0.001$ compared with day 13 on regular diet. thyroid hormone and by phosphate depletion $(2,14,15)$. The possibility of other regulators of vitamin D metabolism, however, is less certain. Although dietary calcium restriction is also known to stimulate production of $1,25(\mathrm{OH})_{2} \mathrm{D}$, this effect is reported to result from the action of parathyroid hormone rather than from that of low calcium per se (14). The effect of calcitonin on vitamin D metabolism has also been controversial. Although Kawashima and associates (5) demonstrated that calcitonin stimulates $25(\mathrm{OH})_{2} \mathrm{D}$ - $1 \alpha$-hydroxylase, in vitro, in the proximal straight tubule of rat kidney, increased plasma levels of $1,25(\mathrm{OH})_{2} \mathrm{D}$ during administration of calcitonin in vivo have either not been observed or the interpretation of experiments has been confounded by the presence of other factors known to influence formation of $1,25(\mathrm{OH})_{2} \mathrm{D}$. For example, Galante and associates (1) reported that 48 -h administration of salmon calcitonin to vitamin $\mathrm{D}$ deficient rats on varying amounts of dietary calcium, caused an increase in $1,25(\mathrm{OH}) \mathrm{D}$ in serum and intestinal mucosa. Lorenc and associates (3), however, using similar conditions, showed that this effect was eliminated by parathyroidectomy, suggesting that the observed calcitonin-dependent increase in $1,25(\mathrm{OH})_{2} \mathrm{D}$ was due to enhanced parathyroid gland function. Conversely, studies by Horiuchi and associates (4) demonstrated that concurrent 30 -h infusion of calcitonin and calcium into TPTX vitamin D-deficient rats resulted in elevated levels of $1,25(\mathrm{OH})_{2} \mathrm{D}$, and that the action of calcitonin and parathyroid hormone on synthesis of the vitamin D metabolite was additive. Although these latter experiments indicated that calcitonin had the potential to stimulate $1,25(\mathrm{OH})_{2} \mathrm{D}$ formation, in agreement with the report of Kawashima et al. (5), they did not show that calcitonin played a physiologic role in modulating production of vitamin D under D-replete conditions, in that vitamin D deficiency, generated prior to TPTX, markedly enhances $25(\mathrm{OH}) \mathrm{D}-1 \alpha$-hydroxylase activity.

The major finding in the present study is the demonstration that chronic infusion of salmon calcitonin increases $1,25(\mathrm{OH})_{2} \mathrm{D}$ plasma levels in vivo in TPTX animals that were deficient neither in vitamin $\mathrm{D}$ nor in calcium. In animals fed a regular diet containing $1.2 \%$ calcium, $1,25(\mathrm{OH})_{2} \mathrm{D}$ levels, after $6 \mathrm{~d}$ of treatment, increased twofold above the control value of $38 \pm 6 \mathrm{pg} \cdot \mathrm{ml}^{-1}$ to $80 \pm 17$. This apparent change in $1,25(\mathrm{OH})_{2} \mathrm{D}$ production was not dependent on parathyroid hormone action in that TPTX had been performed at the onset of the study. The finding of calcitonin-dependent increases in vitamin $\mathrm{D}$ metabolism is consistent with the recent observation that $1,25(\mathrm{OH})_{2} \mathrm{D}$ levels are elevated in patients with medullary carcinoma of the thyroid (16).

It was of interest that further treatment of animals on a regular diet for $13 \mathrm{~d}$ was not associated with a sustained elevation of $1,25(\mathrm{OH})_{2} \mathrm{D}$ levels. This was probably due to higher plasma levels of calcium compared with control, as apparent from inspection of Fig. $1 B$ : clearly the rise in plasma calcium levels and/or body stores of calcium were large enough to offset the stimulation of $25(\mathrm{OH}) \mathrm{D}-1 \alpha$-hydroxylase. After removal of calcium from the diet to blunt the increase in plasma calcium, the $1,25(\mathrm{OH})_{2} \mathrm{D}$ levels rose approximately fivefold in controls $\left(139 \pm 37\right.$ vs. $\left.24 \pm 5 \mathrm{pg} \cdot \mathrm{ml}^{-1}\right)$ and nearly 19 -fold in calcitonintreated animals $\left(460 \pm 50\right.$ vs. $\left.28 \pm 1 \mathrm{pg} \cdot \mathrm{ml}^{-1}\right)$. These results therefore, indicate that calcium, as well as calcitonin, influence $1,25(\mathrm{OH})_{2} \mathrm{D}$ production.

An additional finding of special interest in the present study was that chronic calcitonin administration in animals on a reg- 
ular diet increased plasma calcium levels, an effect that did not occur until approximately day 5 of infusion. This calcium-raising effect of calcitonin might, at first, seem paradoxical since numerous previous studies have shown that acute administration of calcitonin decreases plasma calcium, owing to an inhibition of bone resorption. The acute effect of calcitonin to decrease plasma calcium was also demonstrated in the present study, in experiments in which acute bolus infusion was superimposed on chronic calcitonin infusion (shown in Fig. 3). The present study shows that the rise in plasma calcium was primarily caused by increased intestinal calcium absorption, because the increase in plasma calcium was blunted by removal of calcium from the diet. $^{2}$ It seems likely therefore that the effect of calcitonin on intestinal calcium absorption was mediated by stimulation of $1,25(\mathrm{OH})_{2} \mathrm{D}$ production, although a direct effect of calcitonin on intestinal calcium transport could have also been invoked. However, such an effect has been carefully evaluated in several in vivo and in vitro acute studies which all led to negative results (19-24).

Although Woodhouse and associates (25) previously reported that intestinal calcium excretion decreased in patients with Paget's disease during long-term treatment with intermittent boluses of calcitonin, an observation consistent with increased intestinal calcium absorption, these data provide the first demonstration that chronic calcitonin infusion increases plasma calcium levels in vivo.

Finally, it was of interest that in the calcitonin-treated animals fed the calcium sufficient diet, plasma calcium levels remained elevated (i.e., within the normal range of values) through day 13 although on that day the level of $1,25(\mathrm{OH})_{2} \mathrm{D}$ was not statistically different from control. This apparent inconsistency with the notion that the rise in plasma calcium was caused by increased intestinal absorption of calcium due to elevated levels of $1,25(\mathrm{OH})_{2} \mathrm{D}$ is probably explained by the considerable time lag between the disappearance rate of the hormone from plasma and loss of its biologic effect (26-29), especially in hypoparathyroidism (30).

In conclusion this study suggests that, in addition to parathyroid hormone and phosphate stores, calcitonin and calcium qualify as independent regulators of $1,25(\mathrm{OH})_{2} \mathrm{D}$ production. Moreover, during chronic administration of calcitonin plasma calcium levels are increased due to a rise in intestinal calcium absorption brought about by enhanced levels of $1,25(\mathrm{OH})_{2} \mathrm{D}$. These observations may have important clinical implications since they may provide an explanation, at least in part, for the apparent tolerance to the hypocalcemic effect of calcitonin that has been described during long-term treatment.

\section{Acknowledgments}

The authors are grateful to Dr. F. Caulin, Armour-Montagu Laboratories, for stimulating discussion and Miss Deborah Zalewski and Miss MarieClaude Evraere for preparing the manuscript.

This work was supported by grant AM 18061 from the U. S. Public Health Service. Dr. Jaeger was a recipient of a James Hudson BrownAlexander B. Coxe Fellowship and from a grant from the SICPA Foundation during the course of these studies.

2. It is noteworthy that in calcium-free diet, calcitonin led to a small, albeit significant, $16 \%$ increment in plasma $\mathrm{Ca}$ level. This might be explained at least in part by the anti-calciuretic effect of calcitonin (17) known to take place at the distal site of the nephron (18).

\section{References}

1. Galante, L., K. W. Colston, S. J. Macauley, and I. MacIntyre. 1972. Effect of calcitonin on vitamin D metabolism. Nature (Lond.). 238:271-273.

2. Rasmussen, H., M. Wong, D. Bile, and D. B. P. Goodman. 1972. Hormonal control of the renal conversion of 25-hydroxycholecalciferol to 1,25-dihydroxycholecalciferol. J. Clin. Invest. 51:2502-2504.

3. Lorenc, R., Y. Tanaka, H. F. Deluca, and G. Jones. 1977. Lack of effect of calcitonin on the regulation of vitamin D metabolism in the rat. Endocrinology. 100:468-472.

4. Horiuchi, N., H. Takahashi, T. Matsumoto, N. Takahashi, E. Shimazawa, T. Suda, and E. Ogata. 1979. Salmon calcitonin-induced stimulation of $1 \alpha, 25$-dihydroxycholecalciferol synthesis in rats involving a mechanism independent of adenosine $3^{\prime}: 5^{\prime}$-cyclic monophosphate. Biochem. J. 184:269-275.

5. Kawashima, H., S. Torikai, and K. Kurokawa. 1981. Calcitonin selectively stimulates 25 -hydroxyvitamin $\mathrm{D}_{2}-1-\alpha$-hydroxylase in proximal straight tubule of rat kidney. Nature (Lond.). 291:327-329.

6. Jaeger, P., J. P. Bonjour, B. Karlmark, B. Stanton, R. G. Kirk, T. Duplinsky, and G. Giebisch. 1983. Influence of acute potassium loading on renal phosphate transport in the rat kidney. Am. J. Physiol. 245: F601-F605.

7. Schon, D. A., P. Silva, and J. P. Hayslett. 1974. Mechanisms of potassium excretion in renal insufficiency. Am. J. Physiol. 227:13231330.

8. Fraher, L. J., S. Adami, T. L. Clemens, G. Jones, and J. L. H. O'Riordan. 1983. Radioimmunoassay of 1,25-dihydroxy vitamin $\mathrm{D}_{2}$ : studies on the metabolism of vitamin $\mathrm{D}_{2}$ in man. Clin. Endocrinol. 18: 151-165.

9. Connerty, H. V., and A. R. Briggs. 1966. Determination of serum calcium by means of orthocresolphtalein complexone. Am. J. Clin. Pathol. 45:290-296.

10. Daly, J. A., and G. Ertingshausen. 1972. Direct method for determining inorganic phosphorus in serum with the 'centrifichem.' Clin. Chem. 18:263-266.

11. Friedman, J., W. Y. W. Au, and L. G. Raisz. 1968. Response of fetal bone to thyrocalcitonin in tissue culture. Endocrinology. 82:149156.

12. Keeler, R., V. Walker, and D. H. Copp. 1970. Natriuretic and diuretic effects of salmon calcitonin in rats. Can. J. Physiol. Pharmacol. 48:838-841.

13. Katz, A. I., and M. D. Lindheimer. 1977. Actions of hormones on the kidney. Annu. Rev. Physiol. 39:97-134.

14. Hughes, M. R., P. F. Brumbaugh, M. R. Haussler, J. E. Wergedal, and D. J. Baylink. 1975. Regulation of serum 1,25-dihydroxyvitamin $D_{3}$ by calcium and phosphate in the rat. Science (Wash. DC). 190:578579.

15. Garabedian, M., M. F. Holick, H. F. Deluca, and I. T. Boyle. 1972. Control of 25-hydroxycholecalciferol metabolism by parathyroid glands. Proc. Natl. Acad. Sci. USA. 69:1673-1676.

16. Emmertsen, K., F. Melsen, L. Mosekilde, B. I. Lund, B. J. Lund, O. H. Sorrensen, H. E. Neilsen, H. Solling, and H. H. Hansen. 1982. Altered vitamin D metabolism and bone remodeling in patients with medullary thyroid carcinoma and hypercalcitoninemia. Metab. Bone Dis. 4:17-23.

17. Di Stefano, A., L. M. Elalouf, J. M. Garel, and C. de Rouffignac. 1985. Modulation by calcitonin of magnesium and calcium urinary excretion in the rat. Kidney Int. 27:394-400.

18. Elalouf, J. M., N. Roinel, and C. de Rouffignac. 1983. Stimulation by human calcitonin of electrolyte transport in distal tubules of rat kidneys. Pflügers Arch. Eur. J. Physiol. 399:111-118.

19. Gray, T. K., F. A. Bieberdorf, and J. S. Fordtran. 1973. Thyrocalcitonin and the jejunal absorption of calcium, water, and electrolytes in normal subjects. J. Clin. Invest. 52:3084-3088.

20. Swaminathan, R., J. Ker, and A. D. Care. 1974. Calcitonin and intestinal calcium absorption. J. Endocrinol. 61:83-94. 
21. Olson, E. B., H. F. DeLuca, and J. T. Potts, Jr. 1972. Calcitonin inhibition of vitamin D-induced intestinal calcium absorption. Endocrinology. 90:151-157.

22. Kisloff, B., and E. W. Moore. 1977. Effects of intravenous calcitonin on water, electrolyte and calcium movement across in vivo rabbit jejunum and ileum. Gastroenterology. 72:462-468.

23. Cramer, C. F. 1973. Effect of salmon calcitonin on in vivo calcium absorption in rats. Calcif Tissue Res. 13:169-172.

24. Walling, M. W., T. A. Brasitus, and D. V. Kimberg. 1977. Effects of calcitonin and substance $\mathrm{P}$ on the transport of $\mathrm{Ca}, \mathrm{Na}$ and $\mathrm{Cl}$ across rat ileum in vitro. Gastroenterology. 73:89-94.

25. Woodhouse, N. J. Y., M. Reiner, P. J. Bordier, D. N. Kalu, M. Fisher, G. V. Forster, G. F. Joplin, and I. MacIntyre. 1971. Human calcitonin in the treatment of Paget's disease. Lancet. i:1139-1143.

26. Brickman, A. S., J. W. Coburn, S. G. Massry, and A. W. Norman.
1974. 1,25-dihydroxyvitamin $\mathrm{D}_{3}$ in normal men and patients with renal failure. Ann. Intern. Med. 80:161-168.

27. Rosen, J. F., A. R. Fleischman, L. Finberg, J. Kisman, and H. F. DeLuca. 1977. 1,25-dihydroxycholecalciferol: its use in the longterm management of idiopathic hyperparathyroidism in children. J. Clin. Endocrinol. Metab. 45:457-468.

28. Tanaka, Y., and H. F. DeLuca. 1974. Role of 1,25-dihydroxyvitamin $\mathrm{D}_{3}$ in maintaining serum phosphorus and curing rickets. Proc. Natl. Acad. Sci. USA. 71:1040-1044.

29. Levine, B. S., F. R. Singer, G. F. Bryce, J. P. Mallon, O. N. Miller, and J. W. Coburn. 1985. Pharmacokinetics and biologic effects of calcitriol in normal humans. J. Lab. Clin. Med. 105:239-246.

30. Kanis, J. A., and R. G. G. Russel. 1977. Rate of reversal of hypercalcaemia and hypercalciuria induced by vitamin $D$ and its $1 \alpha$ hydroxylated derivatives. Br. Med. J. 1:78-81. 